\title{
PENGENDALIAN BIAYA BAHAN BAKU PRODUKSI MELALUI SISTEM PENGENDALIAN AKTIFITAS DALAM ANALISA RANTAI NILAI PRODUKSI PERUSAHAAN
}

\author{
Ivana Laksmono ${ }^{a}$ \\ Debby Ratna Daniel ${ }^{b}$ \\ ${ }^{a}$ Sekolah Pascasarjana Universitas Airlangga ${ }^{b}$ Fakultas Ekonomi dan Bisnis Universitas Airlangga \\ Email: ivanalaksmono@inbox.lv ${ }^{a}$; debby-r-d@feb.unair.ac.id ${ }^{b}$
}

ARTICLE HISTORY
Received:
1 June 2020
Revised
15 June 2020
Accepted:
19 July 2020
Online available:
24 November 2020
Keywords:
Sistem pengendalian
aktifitas,
Rantai nilai produksi,
pengendalian atas
tindakan,
pengendalian
personalia, sistem
produksi, proses
produksi yang
terintegrasi, sistem
persediaan

\section{ARTICLE HISTORY}

Received:

1 June 2020

Revised

15 June 2020

Online available:

\section{ABSTRACT}

Introduction: CV. X merupakan perusahaan roti Wholesaler yang memegang lisensi CJ Culinary Concept Holding dan memiliki 3 gerai (outlet) di Surabaya. Masalah yang dihadapi oleh CV. X adalah terdapatnya selisih saldo persediaan antara pencatatan dan fisik sebesar $25 \%$. Selain itu, masalah-masalah lain yang ada dalam perusahaan adalah hilangnya bahan baku, penyusutan bahan baku segar, rusaknya adonan, sistem handling, dan keterlambatan pengiriman produk jadi ke outlet. Sistem pengendalian aktifitas dengan menggunakan pendekatan rantai nilai produksi merupakan sebuah metode yang dapat diaplikasikan untuk merancang sistem pengendalian pada setiap tahapan dalam proses produksi.

Methods: Penelitian ini menggunakan metode kualitatif eksploratori untuk menganalisis sistem pengendalian yang telah diterapkan perusahaan.

Results: Hasil penelitian menunjukkan bahwa masalah seperti kehilangan bahan baku dan penyusutan bahan baku segar dapat dikendalikan dengan menggunakan sistem pengendalian aktifitas yang menerapkan 3 bentuk dari pengendalian atas tindakan (Behavioral constraints, Preaction reviews, dan Action accountability) dan 3 metode dalam pengendalian personalia ( Selection and placement, Training, dan Job Design and provision of necessary resources). Kedua, adonan yang rusak dalam proses pengolahan dapat diatasi dengan mengubah sistem produksi yang manual menjadi komputerisasi. Ketiga, permasalahan dalam proses distribusi yatu sistem handling dan keterlambatan pengiriman produk jadi ke outlet dapat dikurangi dengan menciptakan sebuah proses produksi yang terintegrasi yang dapat tercermin dari Laporan Produksi per batch. Terakhir, ketidaktersediaan bahan baku di Gudang dan keterlambatan pengiriman bahan baku impor dapat diselesaikan dengan sistem persediaan yang pembeliannya dipicu oleh Order Produksi. Conclusion and suggestion: CV. $\mathrm{X}$ perlu menggunakan sistem pengendalian aktifitas dalam rantai nilai produksi untuk mengendalikan biaya bahan baku dan penelitian selanjutnya mengenai sistem Point of Sales (POS) dan Production Order (PO) perlu dilakukan. 


\section{INTRODUCTION}

Industri makanan, minuman, dan tembakau merupakan lapangan usaha yang sangat menyokong pertumbuhan ekonomi di Indonesia yang meningkat cukup pesat sebesar 3,77\% dari tahun 2008 sampai dengan tahun 2012. Perusahaan roti (bakery) merupakan salah satu bidang usaha dalam industri makanan dan minuman yang perkembangannya cukup pesat dari waktu ke waktu di Surabaya sebesar 36,67\% pada tahun 2008-2013. Selain perkembangannya, perusahaan bakery merupakan bidang usaha yang menyerap penggunaan bahan pokok dalam industri makanan dan minuman tertinggi ke-3 di Indonesia yaitu tepung terigu. $22 \%$ pengguna akhir tepung terigu adalah perusahaan bakery.

CV. X merupakan salah satu perusahaan roti (bakery) di Surabaya yang termasuk dalam golongan Wholesaler dan merupakan perusahaan waralaba yang berdiri sejak tahun 2011. CV. X telah memegang lisensi dan merupakan anggota atau member dari $\boldsymbol{C J}$ Culinary Concept Holding dari Singapura yang memiliki 100 (seratus) outlet di wilayah Asia Pasifik. Selain itu, CV. X merupakan perusahaan roti di Surabaya yang mengambil franchise dari Singapura yang di mana proses produksi harus sesuai dengan standar pemberi franchisor dan yang memiliki keunggulan lebih dibanding pesaingnya yang sama-sama mengambil franchise dari Singapura yaitu BreadTalk.

Sistem produksi merupakan fokus dari studi penelitian utama yang berpengaruh secara besar dalam pertumbuhan atas penjualan dan produksi. Pendekatan rantai nilai (value chain) merupakan sebuah kerangka yang digunakan dalam menyusun aktifitas-aktifitas mulai dari pengadaan bahan baku sampai dengan penyampaian produk kepada pelanggan yang dapat menunjukkan konsistensi perusahaan dalam menjaga mutu dan kualitas produksi. Fokus perusahaan adalah pada perspektif proses internal dalam sistem produksi dan persediaan. Value Chain dalam CV.X berguna untuk menentukan nilai jual produk.Nilai jual produk yang ditetapkan oleh perusahaan berasal dari skema perhitungan yang di dalamnya memuat Beban Pokok Produksi dan Profit/Laba yang diterapkan oleh perusahaan.

Biaya bahan baku sebagai salah satu biaya utama yang ada dalam beban pokok produksi perusahaan yang tampak pada skema perhitungan sebelumnya memiliki dampak positif terhadap peningkatan ataupun penurunan terhadap laba atau profit yang diambil oleh perusahaan. Selain itu, salah satu faktor yang berpengaruh terhadap biaya bahan baku adalah nilai persediaan (inventory) yang merupakan sumber utama dari produksi perusahaan. Laporan Bahan Baku suatu bentuk laporan yang menggambarkan seberapa besar peningkatan atas pembelian bahan baku dan pemakaian bahan baku. Selain itu, fungsi dari laporan ini juga membantu perusahaan untuk mendeteksi adanya permasalahanpermasalahan yang terjadi dalam perusahaan dengan menganalisa selisih antara Laporan Bahan Baku berdasarkan pencatatan dan Laporan Bahan Baku berdasarkan pencatatan fisik. 
Dengan ketidakseimbangan dalam laporan bahan baku, maka hal ini dapat berpengaruh terhadap biaya bahan baku.

Tabel 1.

Permasalahan-Permasalahan Dalam Proses Produksi CV.X

\begin{tabular}{|c|c|c|}
\hline No. & Proses Produksi & Permasalahan \\
\hline 1 & Pengadaan Bahan Baku & $\begin{array}{l}\text { Hilangnya bahan baku pada saat proses } \\
\text { produksi }\end{array}$ \\
\hline 2 & Pengadaan Bahan Baku & $\begin{array}{l}\text { Penyusutan bahan baku yang segar karena } \\
\text { dicuri oleh karyawan (Contoh: Ayam beku) }\end{array}$ \\
\hline 3 & Pengadaan Bahan Baku & $\begin{array}{l}\text { Keterlambatan pengiriman biaya bahan baku } \\
\text { yang berasal dari importir }\end{array}$ \\
\hline 4 & Distribusi & $\begin{array}{l}\text { Perbedaan antara laporan produksi dan } \\
\text { laporan penjualan }\end{array}$ \\
\hline 5 & Distribusi & Hilangnya produk jadi saat penjualan \\
\hline
\end{tabular}

Sumber : Hasil Olahan Data Internal CV. X, 2014

Permasalahan-permasalahan yang ada pada tabel 1.1 menunjukkan adanya beberapa titik-titik lemah dalam sistem pengendalian aktifitas dalam proses produksi yang dibentuk dan diimplementasikan oleh CV. X pada sistem persediaan bahan baku (inventory system). Adapun solusi atas permasalahan-permasalahan yang masih terjadi dalam mengendalikan biaya bahan baku sebagai biaya produksi utama dapat diminimalisasi atau dikurangi melalui perbaikan atas sistem pengendalian aktifitas yang terencana dan baik dengan menggunakan rantai nilai (value chain) pada sistem produksi maupun persediaan yang telah ada dan terstandardisasi.

\section{LITERATURE REVIEW}

\section{Sistem Manufaktur (Manufacturing System)}

Sistem manufaktur diakui sebagai fungsi produksi yang mengkonversi bahan baku menjadi produk jadi yang dikendalikan oleh sebuah sistem yang menampilkan perencanaan dan pengendalian. Hitomi (1996 : 47) menyatakan bahwa sebuah sistem yang baik harus memiliki 3 (tiga) aspek yaitu aspek struktural,aspek transformasional, dan aspek procedural

\section{Sistem Produksi Batch (Batch Production System)}

Sistem produksi yang menggunakan kelompok batch atau kecil disebut dengan production batch (Kachwala and Mukherjee, 2009 : 32). Sebagai tambahan, Murthy (2005:9) berpendapat bahwa perusahaan-perusahaan yang mengaplikasikan sistem produksi batch dapat diklasifikasikan menjadi 3 kategori yaitu memproduksi sekali, memproduksi pada interval waktu yang tidak biasa, dan memproduksi secara periodik.

\section{Biaya Produksi}

Hansen dan Mowen (2011:42-43) menyatakan bahwa biaya produksi merupakan biaya-biaya yang diasosiasikan dengan menghasilkan barang-barang atau perlengkapan dari 
jasa-jasa. Biaya bahan baku diakui sebagai biaya utama dalam produksi karena dapat diukur dan dibebankan langsung kepada produk (Rajasekaran and Lalitha, 2010: 37).

\section{Sistem Pengendalian Proses Produksi}

Dalam upaya perusahaan untuk memperoleh harga yang kompetitif, pengendalian biaya produksi meliputi pengendalian terhadap keseluruhan komponen dan tahapan dalam proses produksi mulai dari penanganan bahan baku sampai dengan penyerahan produk jadi (Bhayangkara, 2008 :9).

\section{Sistem Pengendalian Manajemen}

Kerangka pada perspektif pengendalian manajemen difokuskan pada bagaimana anggota-anggota organisasional dapat termotivasi untuk mengikuti kepentingan organisasional dibanding lainnya ( Pfitzer, 2009 : 58). Pfitzer (2009:59) menjelaskan bahwa sistem pengendalian manajemen dapat dibedakan menjadi tiga hal, namun dalam penelitian ini akan digunakan 2 jenis pengendalian yaitu :

1. Action Control melibatkan sebuah penentuan bahwa para individu-individu dalam organisasi telah melakukan tindakan untuk kepentingan terbaik organisasi. Bentukbentuk pengendalian ini yaitu: behavioral constraints, preaction reviews, action accountability, dan redudancy

2. Personnel Control bertujuan untuk mengendalikan para personalia. Metode-metode yang dapat digunakan untuk mengimplementasikan pengendalian ini adalah: selection and placement, training, dan job design and provision of necessary resources

\section{Value Chain}

Value chain merupakan disagregasi sebuah perusahaan dalam aktifitas-aktifitas yang relevan secara stratejik dalam upaya untuk memahami perilaku dari biaya dan sumbersumber yang muncul dan potensial dari differensiasi (Kannegiesser, 2008 : 10-18). Porter (1986 : 20-21) juga menambahkan bahwa sebuah "value chain" menyediakan sebuah kerangka sistematik yang menampilkan dan mengkategorisasikan aktifitas-aktifitas dalam 9 (sembilan) kategori generik.

\section{RESEARCH METHODS}

Pendekatan yang digunakan dalam penelitian adalah pendekatan kualitatif eksploratory. Unit analisa yang dipergunakan dalam penelitian adalah pengendalian aktifitas yang ada dalam perusahaan baik pada tindakan (action control) dan personalia (personnel control) pada rantai nilai proses produksi perusahaan. Penelitian studi kasus pada CV. X menggunakan pengumpulan data baik data kualitatif maupun data kuantitatif., juga menggunakan data baik primer maupun sekunder. Teknik pengumpulan data yang akan digunakan dalam penelitian ini adalah teknik wawancara mendalam, observasi, dan dokumentasi. 
RESULT AND ANALYSIS

Tabel 2

Sistem Pengendalian yang Telah Diimplementasikan Perusahaan

\begin{tabular}{|c|c|c|c|c|c|c|c|c|c|}
\hline \multirow[b]{2}{*}{ No } & \multirow[b]{2}{*}{ Tahapan } & \multicolumn{4}{|c|}{ Action Control } & \multicolumn{4}{|c|}{ Personell Control } \\
\hline & & 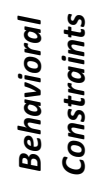 & 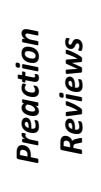 & 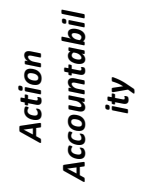 & 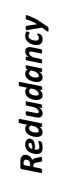 & 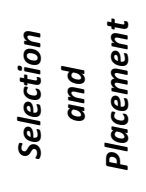 & & 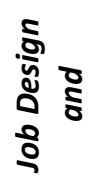 & 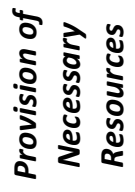 \\
\hline \multicolumn{10}{|c|}{ Tahap Pengadaan Bahan Baku } \\
\hline 1. & $\begin{array}{l}\text { Perencanaan } \\
\text { Bahan Baku }\end{array}$ & $\mathrm{v}$ & $\mathrm{v}$ & & & V & $\mathrm{v}$ & & \\
\hline 2. & $\begin{array}{l}\text { Pembelian } \\
\text { Bahan Baku }\end{array}$ & $\mathrm{v}$ & $\mathrm{v}$ & v & & V & $\mathrm{v}$ & & $\mathrm{v}$ \\
\hline \multicolumn{10}{|c|}{ Tahap Pengolahan Bahan Baku menjadi Produk 1/2 Jadi } \\
\hline 1. & $\begin{array}{l}\text { Pengadukan } \\
\text { Bahan Baku }\end{array}$ & $\mathrm{v}$ & $\mathrm{v}$ & v & & V & $\mathrm{v}$ & & $\mathrm{v}$ \\
\hline 2. & Penyimpanan & v & $\mathrm{v}$ & $\mathrm{v}$ & $\mathrm{v}$ & $\mathrm{V}$ & $\mathrm{v}$ & & $\mathrm{v}$ \\
\hline \multicolumn{10}{|c|}{ Tahap Pengolahan Produk 1/2 Jadi menjadi Produk Jadi } \\
\hline 1. & Pembentukan & $\mathrm{v}$ & $\mathrm{v}$ & $v$ & & V & $\mathrm{v}$ & & $\mathrm{v}$ \\
\hline 2. & Pembakaran & & v & $v$ & & V & v & & \\
\hline 3. & Packing & $\mathrm{v}$ & $\mathrm{v}$ & $\mathrm{v}$ & & $\mathrm{V}$ & $\mathrm{v}$ & & \\
\hline \multicolumn{10}{|c|}{ Tahap Distribusi } \\
\hline 1. & $\begin{array}{l}\text { Penyerahan } \\
\text { Produk Jadi }\end{array}$ & v & $\mathrm{v}$ & v & & V & $\mathrm{v}$ & & $\mathrm{v}$ \\
\hline 2. & $\begin{array}{c}\text { Pengiriman } \\
\text { Produk Jadi ke } \\
\text { Outlet }\end{array}$ & & v & & & V & $\mathrm{v}$ & & $\mathrm{v}$ \\
\hline
\end{tabular}

Sumber: Hasil Olahan Data Internal CV.X, Surabaya

\section{Permasalahan-Permasalahan Dalam Sistem Produksi CV. $\mathrm{X}$}

Permasalahan-permasalahan yang ada dalam CV.X pada setiap tahapan dalam proses produksi yang telah dijelaskan sebelumnya menunjukkan titik-titik kelemahan dalam sistem yang berlaku dalam perusahaan. Hal ini dapat digambarkan melalui diagram tulang ikan (Fisbone diagram) yang menunjukkan sebuah hubungan sebab-akibat.

\section{Gambar 1}

\section{Fishbone Diagram}




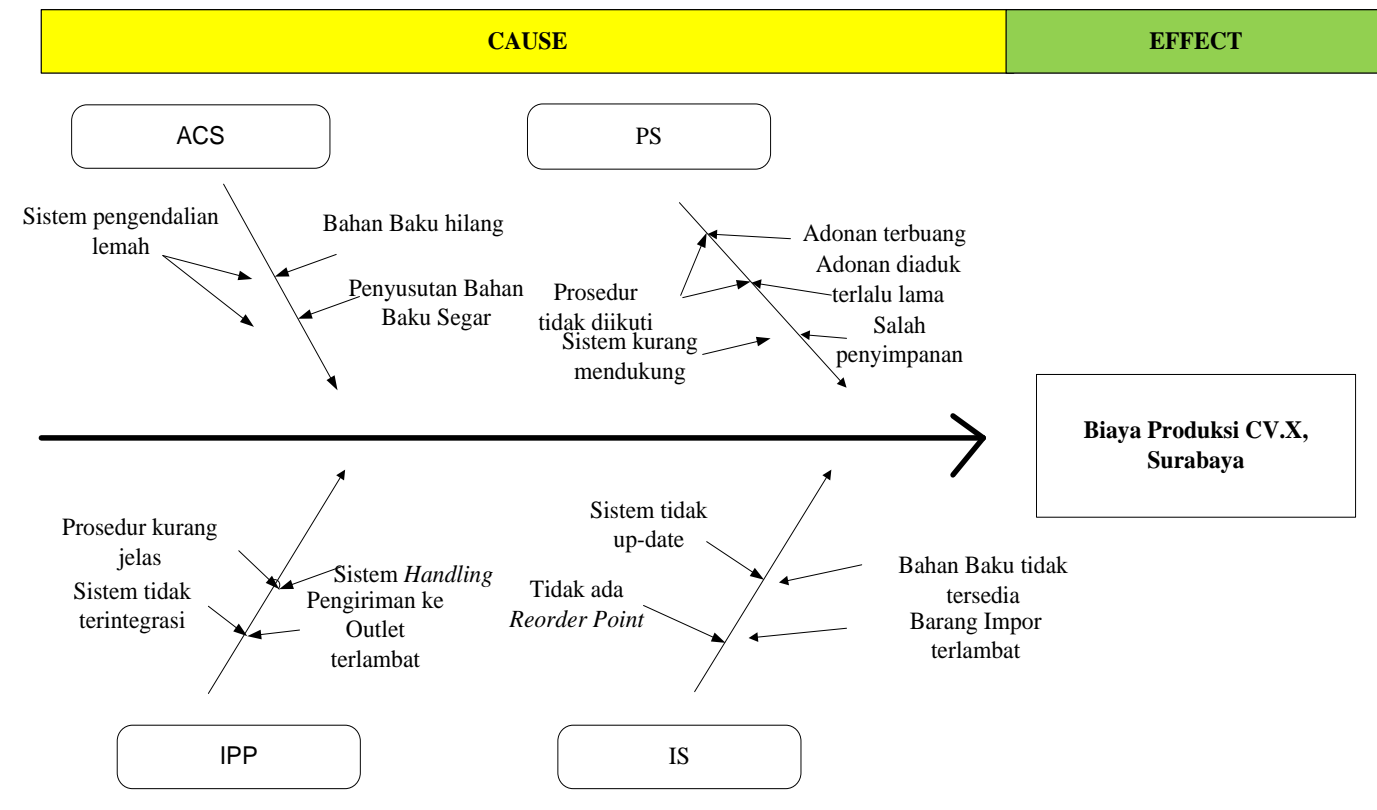

Sumber : Hasil Olahan Data Internal CV. X, 2014

Dalam tahapan-tahapan proses produksi yang telah dijelaskan sebelumnya, terdapat beberapa permasalahan-permasalahan yang dapat dijabarkan sebagai berikut :

1. Tahap Pengadaan Bahan Baku
a. Ketidaktersediaan Bahan Baku di Gudang pada saat dibutuhkan
b. Bahan baku yang tersedia di supplier tidak ada
c. Keterlambatan barang impor
d. Hilangnya bahan baku

2. Tahap Pengolahan Bahan Baku menjadi Produk $1 / 2$ Jadi
a. Terbuangnya adonan karena salah satu bahan lupa dimasukkan
b. Waktu pengadukan terlalu lama sehingga adonan rusak
c. Keterlambatan penyimpanan adonan

3. Tahap Pengolahan Produk $1 / 2$ Jadi menjadi Produk Jadi
a. Rusaknya adonan karena kecerobohan staff produksi
b. Penyusutan Bahan Baku segar
c. Produk gagal karena kecerobohan staff produksi

4. Tahap Distribusi
a. Keterlambatan pengiriman ke outlet
b. Sistem handling

\section{CONCLUSION}

Kesimpulan yang dapat diambil dari hasil penelitian mengenai Pengendalian Biaya Bahan Baku Produksi Melalui Sistem Pengendalian Aktifitas Dalam Analisa Rantai Nilai Produksi pada perusahaan Bakery $X$ di Surabaya adalah kehilangan bahan baku dan 
penyusutan bahan baku segar yang berdampak pada peningkatan biaya bahan baku produksi disebabkan oleh lemahnya sistem pengendalian aktifitas yang diimplementasikan oleh perusahaan. Hasil penelitian ini merekomendasikan sistem pengendalian aktifitas yang memenuhi kriteria-kriteria pengendalian atas tindakan (action control) dan personalia (personnel control). Masalah yang terjadi selama proses pengolahan bahan baku yakni adonan yang terbuang, adonan yang rusak karena pengadukan terlalu lama dan kesalahan penyimpanan dapat diatasi dengan mengubah sistem produksi yang berjalan secara manual menjadi terkomputerisasi serta menambahkan entitas Accounting yang berfungsi untuk mengupdate Laporan Produksi secara real-time sebagai pengendali.

Distribusi sebagai langkah akhir dalam proses produksi yang menyalurkan produk jadi ke outlet untuk disampaikan pada pelanggan akhir (end user) juga memiliki beberapa permasalahan seperti sistem handling yang buruk dan terlambatnya pengiriman produk jadi ke outlet. Masalah -masalah ini dapat diselesaikan dengan menerapkan proses produksi yang terintegrasi (Integrated Production Process) antar semua divisi yang terlibat dalam sistem produksi yang tercermin pada Laporan Produksi per batch. Ketidaktersediaan bahan baku di gudang saat dibutuhkan dan keterlambatan pengiriman bahan baku impor dapat diatasi dengan sistem persediaan (Inventory System), di mana sistem pembelian bahan baku dipicu oleh pengurangan bahan baku ketika bagian Produksi meminta bahan baku sesuai Order Produksi sehingga mencapai titik minimum persediaan (inventory minimum point).

CV. X seharusnya menggunakan sistem pengendalian aktifitas dengan pendekatan rantai nilai produksi untuk mengendalikan biaya bahan baku produksi seperti yang diusulkan dalam penelitian ini. Penelitian selanjutnya mengenai sistem Point of Sales (POS) dengan Production Order (PO) dapat dilakukan.

\section{REFERENCES}

Allison., Ian, Stratton., Roy and Robey, Drew. 2012. Addressing Food Production Planning and Control Issues Through Information Visualitation: An Agile Development. Communications of the IIMA Journal (Vol. 12 No. 1): 1-10

APTINDO. 2013. Overview Industri Tepung Terigu Nasional Indonesia. www.aptindo.or.id diakses pada 23 April 2014

Balkau., Fritz and Sonnemann., Guido. 2010. Managing Sustainability Performance Through The Value-Chain. Corporate Governance Journal (Vol. 10 No. 1): 46-58

Bayangkara, IBK. 2008. Audit Manajemen: Prosedur dan Implementasi. Jakarta: Salemba Empat

BreadTalk Indonesia,2014. www.breadtalks.com diakses pada 24 April 2014

Choi., H. Paul, Blocher., James D., amd Gavinerni., Srinagesh. 2008. Value of Sharing Production Yield Information in a Serial Supply Chain. Production and Operations Management Journal (Vol. 17 No. 6): 614-625

Published by University of Airlangga.

This is an open access article under the CC BY license (https://creativecommons.org/licenses/by-sa/4.0/) 
Chong.,Wang and Xiao-Bing., Liu. 2013. Integrated Production Planning and Control : A MultiObjective Optimization Model. Journal of Industry Engineering and Management

Commercial Global Data Research. 2014. Buku Kondisi Pasar Prospek Industri Tepung Terigu di Indonesia . commercialglobaldataresearch.com diakses pada 23 April 2014

Crystal Jade. 2013. Singapore's Stronger Brand. www.superbrands.com diakses pada 01 Februari 2014

Crystal Jade. 2014. www.crystaljade.com diakses pada 01 Februari 2014

Gellinas., Ulric, Dull., Richard B., and Wheeler.,P.R.. 2012. Accounting Information System $9^{\text {th }}$ Edition. USA: South-Western

Gerrefy., Gary. 2011. Global Value Chains and International Competition. The Antitrust Bulletin (Vol. 56 No. 1): 37-56

Hall, James A. 2013. Accounting Information System $8^{\text {th }}$ Ed. USA: South Western

Higashi.,H., Truong., K.D., Barendregt.,J.J., Nguyen P.K., Vuong., M.L., Nguyen., T.T., Hoang., P.T., Wallace., A.L., Tran,T.V., Le.,C.Q., and Doran.,C.M.. 2011. Cost Effectiveness of Tobbaco Control Policies in Vietnam. Appl Health Econ. Health Policy Journal (Vol. 9 No. 2): 183-196

Hitomi, Katsundo. 1996. Manufacturing System Engineering $2^{\text {nd }}$ Edition. London: Taylor and Francis

I, Raschid., E., Heike., and Ceyp., Michael. 2007. Strategic and Tactics in Supply Chain Event Management. Berlin : Springer-Verlag

Jabbour, Ana B. L. S., Filho., A. G. A., Vianan., A. B. N., and Jabbour, C. J. C.. 2011. Relationships Between Company Size, Production System, and Supply Chain. Journal of Advances in Management Research (Vol. 8 No.1): 30-82

Kannegieser., Mathias. 2008. Value Chain Management in The Chemical Industry. Berlin: Physica-Verlag

Kapil., Sheeba. 2011. Financial Management. India : Darling Kindersley Ltd.

Kementerian Perindustrian. Laporan Kinerja Sektor Industri dan Kinerja Kementerian Perindustrian Tahun 2012. www.kemenperin.go.id diakses pada 01 Februari 2014

Merchant,K.A.. 2003. Modern Management Control System. New Jersey: Prentice Hall

Mhada.,F., Hajji.,A., Malhame., R., Gharbi., A., and Pellerin,R.. 2011. Production Control of Unreliable Manufacturing Systems Producing Defective Items. Journal of Quality in Maintenance Engineering (Vol. 17 No. 3): 238-253

Mukherjee., P. N. and Kachwala., T. T.. 2009. Operations Management and Productivity Techniques. New Delhi : PHI Learning Private Limited

Murthy.,P. Rama. 2005. Production and Operations Management System. New Delhi : New Age International $(P)$ Limited

Mowen.,Maryanne M. and Hansen., Don R.. 2011. Managerial Accounting $8^{\text {th }}$ Edition. USA: Thomson South-Western

MY Khan, PK Jain. 2007. Management Accounting $4^{\text {th }}$ Edition. New Delhi: Tata Mc Graw-Hill

Needles.,B., Powers.,M., and Crosson.,S. 2010. Principles of Accounting $11^{\text {th }}$ Ed. SouthWestern : Cengage Learning

Njike., Archille N., Pellerin., Robert., and Kenne, Jan Pierre. 2012. Simultaneous Control of Maintenance and Production Rates of a Manufacturing System With Defective Product. Science and Business Journal (Vol. 23): 323-332 
OECD. 2013. Interconnected Economies: Benefiting From Global Value Chain. Victoria : OECD Publishing

Pfitzer, Jan A.. 2009. Managing Organizational Culture for Effective Internal Control. Berlin: Physica-Verlag

Plaza Franchise. Daftar Perusahaan Dengan Sistem Franchise di Indonesia. www.plazafranchise.com diakses 23 April 2014

Porter, Michael E.. 1986. Competition in Global Industries. Boston : Harvard Business School Press

Rich.,J., Jones., J. P., Heitger., D. L., Mowen., M. M . and Hansen, Don R.. 2010. Cornerstones of Financial and Managerial Accounting. South-Western: Cengage Learning

Shank,John K. and Govindarajan,Vijay. 1993. Strategic Cost Management: The New Tool for Competitive Advantage. USA: The Free-Press

Warren.,C., Reeve.,J. and Duchac,J.. 2012. Accounting. South-Western: Cengage Learning

Yanfang.,Wu. 2012. Research on Cost Strategies in Railway Construction Business Based on Value Chain .Management of Science and Engineering Journal (Vol. 6, No. 3): 59-62

Yellowpages 2008-2013

Yin., K. Robert. 2009. Case Study Research: Design and Methods $4^{\text {th }}$ Edition. USA: Sage Publication,Inc.

Yin., K. Robert. 2011. Applications of Case Study Research. USA: Sage Publication,Inc.

Zhang., Yufeng and Gregory., Mike. Managing Global Network Operatios Along The Engineering Value Chain. International Journal of Opertions and Production Management (Vol. 31 No. 7): 736-764

Zylberberg., Ezequiel. 2013. Bloom or Bust? A Global Value Chain Approach to Smallholder Production in Kenya. Journal of Agribusiness and Emerging Economies (Vol. 3 No. 1): 425 